\title{
"Fdi and Economic Growth" A Study from Pakistan
}

\author{
Muhammad Nadeem ${ }^{1}$, Ammar Ahmed \\ Faculty Of Management Sciences Bahauddin Zakariya University Multan Pakistan \\ Faculty Of Management Sciences Bahauddin Zakariya University Multan Pakistan
}

\begin{abstract}
The objective of this paper is to investigate the impact of foreign direct investment (FDI) on gross domestic product (GDP) in Pakistan from 2006 to 2010. The growth of gross domestic product (GDP) is also measured in this study. Multiple regression model is used to measure the association among gross domestic product (GDP,) foreign direct investment and Inflation. FDI and inflation (CPI) are independent variables and GDP is dependent variable. There is positive and significant connection between GDP and FDI but a negative and significant relationship found between GDP and inflation.
\end{abstract}

Keywords: GDP, FDI, CPI.

\section{INTRODUCTION}

Foreign direct investment (FDI) is the source of increasing investment in the country. Foreign direct investment has its more importance in the developing countries because this investment opens the door of opportunities of investments. Foreign direct investment increases the foreign reserves of the country which also increases the significance of the foreign direct investment for the developing countries like Pakistan. Foreign direct investment is very famous in developing countries for increasing economic development.

According to Muhammad (2007) foreign direct investment is one of the most effective factors for rapid growth of the country. The investments in the developing countries from the other countries are decreasing at present. Foreign direct investment increases the capital of the country but also overall productivity, efficiency of the country. Foreign direct investment increases the opportunities of employment in the country. Foreign direct investment is source of technological advancement in the country which is helpful in increasing the exports of the countries. For better utilization of the resources of the countries, foreign direct investment is the major source of getting funds for the developing countries.

For successful business development in the country, foreign direct investments are necessary and it also useful to create a good image of the country in the mind of the foreign investors. Due to foreign direct investments people get chance to attain new skills, knowledge and training. All those developing countries which are having low foreign direct investments are facing problems in rapid growth and technological advancements. Foreign direct investment for the developing countries has its own importance.

The objective of this study is to examine the impact of foreign direct investment in Pakistan on economic growth for the period of five years (2006-2010). Pakistan is a developing country and population of Pakistan is increasing rapidly. Pakistan is basically an agrarian country whose population depends upon agriculture sector. Most part of the population lives under poverty because of lack of resources. Per capita income is very low and economic growth is also slow that is why importance of foreign direct investment also increases for Pakistan. Inflation rate is high in Pakistan whereas per capita income is low which one of the major problems in Pakistan is. FDI and Inflation plays a very vital role in its future growth and development. Although Pakistan has natural resources, human resources but it is facing many problems to compete with other countries in the world because of its wrong policies and strategies.

\section{LITERATURE REVIEW}

Importance of foreign direct investment cannot be denied in any country. Governments always try to make the policies, strategies with the intensions to help, support and facilitate the foreign investors as much as possible. According to Abbas et al (2011) Governments of the developing countries are more conscious and facilitate the foreign investment more than developed countries because their economic growth and development is more depending on the confidence and interest of the foreign investors. Pakistan is also one of those developing countries

\footnotetext{
${ }^{1}$ Corresponding Author: muhammadnadeem19@gmail.com
} 
which make policies to attract and get the interest of the foreign investors. Developing countries direct and support the foreign investors to invest in the right places to get the returns successfully.

Many researchers have worked on the importance and significance of the foreign direct investment and its effect on the economic growth but most of the studies have been conducted in the developed countries. Some researchers found positive whereas others found negative association between foreign direct investment and economic growth.

Ahmad et al (2003) described that the significance and advantages of foreign direct investment are much superior in those countries that follow export encouragement policies. Herzer et al (2008) discussed that the benefits foreign direct investment grants profit with no which gives the steady growth path. Adam \& Tweneboah (2009) use parallel development outline to study benefits and growth dynamics of foreign direct investment. Foreign investment is useful to lift up per capita income in the host country on everlasting basis if foreign investors show their interest and consign to re-invest their profits in the host country. The study discussed that such a opportunity can be present only in the countries with very low saving rate and/or high share of capital in the national income. Chandab \& Ozcanc (2004) discussed that foreign direct investment has positive effect not only on the economic growth but also on the image, perception of other countries about Ghana in the world. The study also discussed that stock exchange positively linked and associated with the foreign direct investment because it raises the confidence of the investors and creditors. Foreign direct investment is beneficial for the economy and effect economic growth positively not only in the short run but also in the long run.

Falki in (2009) and Agarwal in (2000) described that the link between the foreign direct investment and economic growth is negative but they have not denied from the significance and importance of the effect of the foreign direct investment on the economic growth. Falki in (2009) in his statistical analysis from 1980 to 2006 found that foreign direct investment has significant and negative effect on economic growth. Agarwal in (2000) described that in the south Asian countries there was negative association between foreign direct investment and economic growth till 1980. Failure of this may be the inefficient utilization of foreign direct investment. Mubarik in (2005) found negative relationship between inflation and economic growth in Pakistan. Khan and Senhadji (2001) described that there is negative relationship between inflation and economic growth not only in developing countries but also in the developed countries. They analyzed data of 140 developed and developing countries and showed the negative linkage between inflation and economic growth. Munir et al (2009) found negative relationship between inflation and economic growth in Malaysia.

\section{Methodology}

The objective of this study is to measure the linkage between foreign direct investment and economic growth and inflation in Pakistan from 2006 to 2010. Secondary data is gathered from different sources to measure the results. To study the link between foreign direct investment and economic growth and inflation in Pakistan theoretical model is used.

$\mathbf{G D P}=\mathrm{a}+\mathrm{b} \mathbf{1} \mathbf{F D I}+\mathrm{b} \mathbf{2} \mathbf{C P I}+\boldsymbol{\mu}$

Where,

FDI $=$ Foreign Direct Investment

GDP $=$ Gross Domestic Product

CPI = Inflation Rate

Level of Significant: 5 to 10 percent

To study the Impact of FDI and CPI on the Gross Domestic Product of Pakistan Multiple Regression Model was used. Dependent variable was GDP whereas FDI and CPI are measured as independent variables. To measure the effect of FDI on GDP of Pakistan, Multiple Regression Model is applied over the period of 2006 to 2010.

Table1. Results of GDP, FDI and CPI

\begin{tabular}{|l|l|l|l|l|r|}
\hline Variable & Coefficients & T Values & P Values & F Statistics & R Square \\
\hline FDI & 0.354556 & 13.36547 & 0.001 & 179.1457 & 0.895391 \\
\hline CPI & -1.117465 & -14.49281 & 0.000 & & \\
\hline
\end{tabular}


Foreign direct investment showing positive impact on GDP in the multiple regression analyses whereas inflation has negative impact on GDP. If one percent change in FDI occurs, it will bring about $0.35 \%$ change in GDP while 1 percent change in CPI will bring- $1.11 \%$ change in GDP by holding other variables constant. Value of $\mathrm{F}$ showing that foreign direct investment and CPI are highly significant. Value of P is 0.001 for foreign direct investment and 0.000 for inflation. Model is overall very much significant. The $r$-square of this model is 0.89 .

\section{CONCLUSION}

Foreign direct investment play an important role in a country for economic growth but its importance in the developing countries is much more. Foreign direct investment in a country shows interest and confidence of other countries and investors on the host country which is positively associated with the economic growth and GDP. Economic, political and social situation of the country is also important for increasing foreign direct investment in the country. Proper guidance, benefits and opportunities should be available in the country for the foreign investors to raise their interest. Government of the country should make policies and strategies which are favorable for the investors. Government must understand the reservations of the foreign investors so that they can also attain their desired goals. Importance of foreign investors increases much more in the developing countries like Pakistan.

\section{LIMITATIONS AND RECOMMENDATIONS}

The results of the test show that an increase in FDI has positive impact on growth rate of Pakistan. The results of the research must be interpreted carefully and thoroughly. This is related to a number of limitations which can be used as a basis for making recommendations. Limited time period is used from 2006 to 2010 (five years) for this research study whereas in future longer time period can be used for better results. In our study effect of foreign direct investment is linked with the GDP and inflation but in future effect of foreign direct investment can be measured on employment, national income etc. Policy makers should think and understand the importance of foreign direct investment and its effect on GDP while making the policies. They must encourage and facilitate foreign investors to increase the foreign direct investment which will also help to increase the foreign reserves of the country. Business friendly environment should be provided to the foreign investors and proper guidance should be provided to the investors.

\section{REFERENCES}

[1] Abbas, Q., Akbar, S., Nasir, A., Amanullah, H. \& Naseem, M. (2011) Impact of Foreign Direct Investment. Global Journal of Management and Business Research, Volume 11 Issue 8 Version

[2] Adam, A. \& Tweneboah, G. (2009) Foreign Direct Investment and Stock Market Developments. International Research Journal of Economics Issue, 26.

[3] Agrawal, P. (2000). Economic Impact of Foreign Direct Investment in South Asia, Indra Gandhi Institute of Development Research.

[4] Ahmad, M.H., Alam, S. And Butt, M.S. (2003) Foreign Direct Investment, Exports, and Domestic Output in Pakistan. The Pakistan Development Review, Vol. 42, No.4, pp. 715-723

[5] Chandab, A. \& Ozcanc, S. (2004) FDI and economic growth: the role of local financial markets. International Economics issue, (64) page 89-112.

[6] Falki, N. (2009) Impact of Foreign Direct Investment on Economic Growth in Pakistan, Review of Business Research Papers Vol. 5 No. 5

[7] Herzer, D., Klasen, S., Nowak, F., \& Lehmann, D. (2008) In Search of FDI-led Growth in Developing Countries. Proceedings of the German Development Economics Conference, Research Committee Development Economics.

[8] Khan, M. S. and Senhadji, A. (2001) Threshold Effects in the Relationship between Inflation and Growth, IMF Staff Papers, 48:1

[9] Mubarik, Y (2005) Inflation and Growth: An Estimate of the Threshold Level of Inflation in Pakistan. State Bank of Pakistan Research Bulletin, Vol. 1(1)

[10] Muhammad, A. (2007) Economic Growth and Foreign Direct Investment: The Role of Domestic Financial Sector, PIDE Working Papers 2007:18

[11] Munir, Q., Mansoor,Q. \& Furuoka, F. (2009) Inflation and Economic Growth in

[12] Malaysia: A Threshold Regression Approach, ASEAN Economic Bulletin, 26(2), 180-193. 